\title{
CURRENT SAFETY DATA OF THE COMPLEX HERBAL MEDICINE WITH SEDATIVE AND CARDIOPROTECTIVE ACTIONS
}

\author{
N. Gorchakova ${ }^{1}$, E. Heimuller ${ }^{2}$, A. Galkin ${ }^{3,4 *}$ \\ ${ }^{1}$ Alexander Bogomolets National Medical University, Kyiv, Ukraine \\ ${ }^{2}$ Dr. Gustav Klein GmbH \& Co. KG, Germany \\ ${ }^{3}$ Igor Sikorsky Kyiv Polytechnic Institute, Kyiv, Ukraine \\ ${ }^{4}$ UA PRO-PHARMA LLC, Kyiv, Ukraine \\ *Corresponding author: alexfbt@gmail.com
}

Received 5 September 2018; Accepted 28 September 2018

Background. The risk management plan is the one of main documents of pharmacovigilance system -
a document focuses on the planning of pharmacovigilance activities and minimization of risks. As the use of
herbal medicines has increased, so too have the reports of suspected toxicity and adverse events. As many
herbal products on the market have not been thoroughly tested for their pharmacology and toxicology,
pharmacovigilance has paramount importance in detecting unwanted reactions. One of the herbal prepara-
tions widely used to support the cardiovascular system under stress, neurocirculatory dystonia, cardiac neuro-
sis, in the complex treatment of arterial hypertension, angina pectoris, arrhythmia is a complex medicinal
product Carvelis, oral drops, solution. The active pharmaceutical ingredients of the drug are: extract from a
mixture of hawthorn leaves, flowers and fruit (Crataegi folii cum flore, fructus extractum); herb extract of
canine nettle (Leonuri herbae extractum); melissae herbia extract Melissae herbae extractum); valerian root
extract (Valerianae radix extractum). Objective. Critical analysis of current scientific data on the benefit/risk ratio of a complex herbal medicine with sedative and cardioprotective effects.

Results. Pathophysiological and epidemiological characteristic of following nosological forms have been analyzed: stress, neurocirculatory dystonia, cardiac neurosis, arterial hypertension, angina pectoris, arrhythmia. Current data on phytopreparation safety and estimation benefit/risk ratio have been generalized. Available clinical data were analyzed for individual phytocomponents or its combinations.

Conclusions. The prevalence, seriousness and severity of the course of all manifestations of neurocirculatory dystonia, stress, nervous excitement, heart neurosis, especially with disproportionate approaches to the treatment of these diseases, is a serious medical and social problem. Given the proven efficacy of the use of Carvelis preparation components, and also that the risks are predictable, and their occurrence can be countered, and if they occur it can be effectively suppress with other drugs, the benefit of using the phytopreparation prevails above the risks.

Keywords: pharmacovigilance; risk management plan; hawthorn; motherwort; valerian; melissa.

\section{Introduction}

Pharmacovigilance is the pharmacological science, the part of modern health care aimed at ensuring the safety of patients in the use of drugs, reducing morbidity and mortality. Marketing authorization holders are obliged to create, provide and guarantee the functioning of their own pharmacovigilance system. And it is a prerequisite for presence of medicines in the market. Now the main vector of pharmacovigilance in developed countries is the transition from reactive (case detection - and response to proactive) to proactive (planning and prevention of cases) management. There are three main documents of pharmacovigilance system, and they are focused on organization quality management, as well as on certain prepara- tion pharmacovigilance data. The first of them is risk management plan - a document containing a detailed description of the risk management system and focuses on the planning of pharmacovigilance activities and minimization of risks. The second one is periodic safety update report (PSUR) - a document that focuses on analyzing available cumulative and interval information on the safety and efficacy of the certain medicinal product and assessing the benefit/risk ratio. And the third important document is addendum to clinical overview a document that contains a critical analysis of the current benefit/risk profile of the certain medicinal product conducted on the basis of PSUR data, as well as on safety and efficacy data collected from the time of the first registration or last reregistration of medicinal product. Proactive man- 
agement allows you to manage the risks associated with drugs, both among the population, and in the work of pharmaceutical companies and regulators [1-4].

As the use of herbal medicines has increased, so too have the reports of suspected toxicity and adverse events. Such unwanted reactions can be due to (i) side effects (usually detectable by pharmacodynamics and often predictable); (ii) reactions occurring as a result of overdose, overduration, tolerance, dependence-addiction (detectable either by pharmacodynamics or pharmacovigilance), (iii) hypersensitivity, allergic and idiosyncratic reactions (detectable by pharmacovigilance), (iv) mid-term and long-term toxic effects including liver, renal, cardiac and neurotoxicity also genotoxicity and teratogenicity (detectable by in vitro and in vivo toxicological studies or by pharmacovigilance). As many herbal products on the market have not been thoroughly tested for their pharmacology and toxicology, pharmacovigilance has paramount importance in detecting unwanted reactions [5].

One of the herbal preparations widely used to support the cardiovascular system under stress (stress), neurocirculatory dystonia, cardiac neurosis, in the complex treatment of arterial hypertension, angina pectoris, arrhythmia is a complex medicinal product Carvelis, oral drops, solution (Dr. Gustav Klein GmbH \& Co. KG, Germany). The active pharmaceutical ingredients of the drug are: extract from a mixture of hawthorn leaves, flowers and fruit (Crataegi folii cum flore, fructus extractum); herb extract of canine nettle (Leonuri herbae extractum); melissae herbia extract Melissae herbae extractum); valerian root extract (Valerianae radix extractum).

The purpose of this article is a critical analysis of current scientific data on the benefit/risk ratio of a complex herbal medicine with sedative and cardioprotective effects.

\section{Pathophysiological and epidemiological charac- teristic of nosological forms for the treatment of which a phytopreparation is prescribed}

Support for the cardiovascular system at nervous tension (stress). Stress is a nonspecific reaction of the body in response to the strong action of the stimulus from the outside, which exceeds the norm, as well as the corresponding reaction of the nervous system. There are the following types of stress: informational, emotional, physiological and post-traumatic. The activity of the sympathetic nervous system during the period of stress is characterized by an increase in the allocation of "stress" hormones, an increase in the frequency of cardiac contractions, blood pressure. In this case, there are organic changes in the heart, possibly arrhythmias and ischemia. Conditions are also developed for the development of thrombosis, the appearance or progression of atherosclerosis, coronary heart disease. Such a complex of physiological and pathomorphological changes leads to the development and progression of most cardiovascular diseases. There is a direct relationship between the level of stress, daily average blood pressure and heart rate [6].

The tendency to stress of different severity has any individual regardless of socio-economic status. In the United States up to $90 \%$ of the adult population is periodically under stress, $60 \%$ of them are exposed to stress factors 1-2 times a week, and $30 \%$ - every day. At the same time, in $2 / 3$ of cases, an appeal to the doctor is due to diseases and conditions, the basis of development of which lies the effect of stress factors. The annual economic cost of treatment and rehabilitation of stress-affected people in the United States is about $\$ 300$ billion [7].

Data for adult World Trade Center Health Registry enrollees residing in New York State on enrollment and no cardiovascular disease history $(n=46,346)$ were linked to a New York State hospital discharge-reporting system.

The increased risk of hospitalization among patients with cerebrovascular or cardiovascular disease was observed in women (corrective risk factor $1.32,95 \%$ confidence interval 1.01 to 1.71 ) but not men (risk factor correction factor [AHR] 1.16, 95\% confidence interval [CI] from 0.97 to 1.40 ). All patients were characterized by post-traumatic stress disorder. Among those who were evacuated from the World Trade Center or were engaged in restoration, a high level of hospitalization with cardiovascular diseases in men was, at the same time, for women, such data were unclear. Such data primarily relate to the diagnosis of "ischemic heart disease". It should be noted that stress has led to an increase in hospitalizations with cerebrovascular disorders in men, but not in women [8].

The results of the Japan Collaborative Cohort Study for the Assessment of Cancer Risk for the perception of stress were interesting. In this study, more than 70,000 patients aged 40 to 79 years participated. The exclusion criteria were: a stroke, an ischemic heart disease, or cancer in anamnesis. Women who were under severe stress had twice the 
risk of death from stroke and coronary artery disease and 1.5 times higher than the risk of any cardiovascular disease. For men, this dependence was not so pronounced, but chronic stress in men often led to myocardial infarction [9].

Another authors published the results of a 20-year survival study of patients with CHD who were under constant influence of emotional stress [10]. Researchers have shown that in a group of patients who are under the influence of persistently pronounced stress, after 3 years, the survival rate is significantly lower than in the groups of patients with no stress or low intensity stress. At the same time, after 10 and 20 years of observation, this difference was more pronounced.

It should be noted that for the treatment of stress, the following drugs are used: antidepressants, neuroleptics, nootropics, tranquilizers, vitamin therapy (vitamins $\mathrm{B}$ and $\mathrm{C}$ ); aromatherapy, sports, and yoga are also used [11-13].

Neurocirculatory dystonia (NCD) is a symptom of a neurogenic nature that occurs due to the influence of a number of etiological provocative factors, which is manifested in the appearance of instability of the pulse and indicators of blood pressure, cardialgia, respiratory disturbances, autonomic disorders, violations of the tone of muscle fibers and the vascular wall, and also low tolerance to the usual physical activity and the impact of stressful situations. NCD is the result of an autonomic nervous system (ANS) imbalance, so the form of NCD depends on the predominance of a certain part of the ANS (sympathetic or parasympathetic) [14].

NCD cannot be called a complete illness. Most often it is associated with a symptom, the main expression of which is a violation of the cardiovascular, nervous and respiratory systems. It is most often diagnosed in young people, who eventually experience various cardiovascular disorders. The fact that neurocirculatory dystonia is more often diagnosed in young people is due to the fact that in the younger generation there is a discrepancy between physical development and the slow formation of the neuroendocrine system. With regard to the causes of the disease, they include: intoxication, acute and chronic infections, fatigue, regular sleep deprivation, malnutrition, physical overload, frequent changes in sexual partners and stress. In addition, in some patients neurocirculatory dystonia is manifested under the influence of poor heredity. It is now taken to distinguish three types of neurocirculatory dystonia: cardiac, hypertonic and antihypertensive. If reveals are too in- tense and leads to constant irritability or sleep disturbances, following preparations are recommended: phenobarbital, valerian preparations, oxazepam and some other tranquilizers. Medicinal treatment may include: valerian and motherwort based preparations; tranquilizers (tofisopam); antidepressants (amitriptyline); nootropic drugs (piracetam); cerebral angiocorrectors (vinpocetine) [15].

Cardiac neurosis is a functional disorder of the cardiovascular and nervous systems. The pathogenesis is the weakening of the regulatory activity of the cerebral cortex and the associated violation of the functions of the subcortical centers of the autonomic nervous system. Often, the causes of cardiac neurosis are stress, mental health and physical strain. Stress provokes a sharp release of adrenaline, which damages the heart and the judges. An important role in violating the autonomic regulation of the cardiovascular system is the use of coffee, alcohol and smoking. The risk group of this disease includes people of all ages [16-18].

The most common symptom is pain in the sternum and in the area of the heart (with irradiation in the left arm and shoulder blade). Even with insignificant agitation, heart rhythm abnormalities (arrhythmia), a feeling of "heart fading", heartbeat attacks (tachycardia), or severe pulsation, which is felt throughout the body. Manifestation of the following symptoms also is possible: feeling of lack of air or breathlessness, raising the body temperature up to subfebrile level, labile arterial pressure, dyspeptic disorders in the form of vomiting, nausea associated with eating, wheezing, abdominal pain. General weakness, fatigue, even with insignificant physical activity, headaches, signs of asthenia, insomnia or drowsiness, sudden tides of heat or cold are also possible. There are redness of the face and chest, increased sweating, arms and legs begin to dull, paresthesias, limbs are cold to the touch; often there are symptoms such as feelings of sadness, a feeling of tension inside, shaking hands and feet, a feeling of fear of death, tearfulness [16-18].

In the acute period of treatment, the appointment of tranquilizers and beta-blockers is indicated. In the future, medical therapy is aimed at eliminating signs of heart neurosis, sedation and the elimination of unpleasant symptoms, and includes herbal preparations, a complex of vitamins and minerals (high concentration of magnesium and vitamins of group B). Literature data analysis shows that the herbs of choice are hawthorn, valerian, motherwort, passiflora, mentha, yarrow, pot marigold and some others $[17,18]$. 
Hypertension (stage 1 and 2). Stress-induced arterial hypertension is an acute increase in blood pressure under the influence of psycho-emotional factors. It can occur in people with normal blood pressure and those with arterial hypertension [6]. This disease is a problem of young people living in cities. Experts have found that the probability of developing hypertension in rural areas is much lower. In older people, stress provokes heart rate abnormalities. At the same age, the risk of developing a heart attack and stroke increases.

In stress, following physiological parameters are changed: the frequency of cardiac contractions increases, respiration is accelerated, the tone of smooth muscles is changed (including the gastrointestinal tract), diameter of the pupils is changed, increases blood pressure and glucose concentration in the blood. All this leads to the fact that the body becomes a state of preparedness for survival in an extreme situation. But when it happens every day, the mechanisms that are responsible for the functioning of the cardiovascular system in a state of stress come to fruition, as well as pathological changes occur (in any organs associated with blood circulation regulation). All this can lead to a chronological process of increasing blood pressure [19, 20]. The constant effect of stress factors observed during the earthquake in the south of Italy led to a steady increase in blood pressure - an average of $20 \%$ increased systolic and $46 \%$ diastolic arterial pressure [21].

Angina and arrhythmia. Angina pectoris is a kind of coronary heart disease, the main symptom of which is pain syndrome. Angina pectoris is common among mature and elderly people. Both males and females are equally prone to the risk of angina, but in different age periods the incidence is different. Angina occurs due to the development of atherosclerosis in the cardiac arteries. Sudden angina attacks can be caused by excessive excitement, walking, physical activity, smoking, using a large dose of alcohol, staying in a stuffy, dusty, smoky room or in high frost. Usually, pain occurs in the pre-dawn time. Various meteorological, geomagnetic factors, high humidity, atmospheric pressure fluctuations can also provoke the appearance of pain. There are also remote risk factors that accelerate and aggravate the development of angina: diabetes mellitus, obesity, hypodynamia, frequent mental stress, stress, alcoholism, abuse of salty and greasy foods, refined carbohydrates. Symptoms are over after the use of nitroglycerin [22, 23].

Among medical plants containing antiatherosclerotic substances are corn (female inflorescence, with young silk), hawthorn flowers and fruits, rose hips, mountain arnica flowers, Jacob's-ladder roots, elderberry leaves, black chokeberry fruits, common nettle, garlic, beet, and carrots. Herbal infusions will not relieve pain; they have a prophylactic effect, so they should be used for a long time, usually in combination with other preparations $[24,25]$.

Jitters. Excitement is a biological process that consists of nerve impulses and activates one or another body or element. The process of excitation occurs in all organs that consist of the nervous and muscular tissue, and in the glands. A specific sign of muscle arousal is its reduction. In the nerve cells during the excitation, nerve impulses are generated, the glandular cells secrete the secretion. A specific property of excitation is the ability to pass through nerve fibers, which provides a physiological link between all systems and elements of the organism, their functional unity. The best way to suppress anxiety and nervous excitement is to use special medical herbs [6].

\section{Current data on phytopreparation safety and estimation benefit/risk ratio}

The problem of autonomic dysfunction today is one of the main problems of modern medicine. Symptoms of neurocirculatory disorders combined with different manifestations of vegetative imbalance are noted in $21-60 \%$ of all patients, including $25-30 \%$ of patients of therapists and family doctors, and in $30-50 \%$ of cardiac patients [26].

At present, it is generally accepted that neurocirculatory dystonia is an integral part of the clinical picture of neurosis, which, in turn, is the most common cause of neurocyclecular dystonia. Now many forms of neurosis, accompanied by manifestations of NCD, are considered within the framework of a wider range of pathologies - psychosomatic disorders [27].

The pathogenesis of psychosomatic diseases is complex and multifaceted. It involves important in terms of providing the optimal level of neurohumoral regulation of the structure of the central nervous system (CNS), as the hypothalamicpituitary and limbic systems, regulatory centers of the cerebral cortex, adrenal glands, etc. However, it should be emphasized that the main role in the development of psychosomatic pathology is played by the situation of chronic stress. It is chronic stress that is one of the most important factors in the "launching" of a multi-chain mechanism for the development of psychosomatic diseases with a 
predominant lesion, in turn, of the nervous or cardiovascular, digestive or other systems [28].

The most common variant of the clinical course of NCD is cardiovascular syndrome. The greatest clinical significance is NCD, which occurs with the phenomena of hypersympathicotonia, constant or crisis increase in blood pressure and severe tachycardia. The danger of this form of NCD is the increased risk of developing such forms of pathology as coronary artery disease, hypertension, arrhythmias, cerebral circulation disorder, etc. Therefore, adequate pharmacotherapy of this variant of NDC is especially relevant [29].

Correct treatment of autonomic dysfunction is possible with the administration of traditional somatic therapy (antihypertensive preparations, coronary antics, beta-blockers, proton pump inhibitors, etc.) together with neuropharmacological preparations that influence the dynamics of the clinically leading syndromes linked with the central mechanisms of dysregulation.

Psychoemotional imbalance is one of the most common manifestations of vegetative vascular dystonia; it sharply impairs patients' quality of life and ultimately contributes to an increase in the pathogenetic "vicious circle" of stress-induced CNS disorders.

Normalization not only will become a psychoemotional sphere at vegetative vascular dystonia, but also a correction of actually vegetative disorders can be achieved at the expense of appropriate therapeutic means of sedative and vegetative stabilizing action, among which the leading place is occupied with phytopreparations.

Especially popular in recent years have been combined phytopreparations that contribute to the normalization of the central regulatory mechanisms for the development of psychosomatic pathology, which stabilize the cortical subcortical relationship, the violations of which are the basis of vegetative vascular dystonia and psycho-emotional imbalance. The main advantages of herbal preparations include: the possibility of using proven standard effective combinations of biologically active substances in one dosage form; reduction of forced polypragmasia while preserving or increasing the effectiveness of treatment; improvement of compliance (for the patient and the doctor); increasing the economic availability of treatment [30-32].

The phytopreparation drug Carvelis (Dr. Gustav Klein $\mathrm{GmbH} \&$ Co. KG, Germany) in the form of drops for oral use contains all mentioned components (based on $10 \mathrm{ml}$ of solution: an extract of a mixture of hawthorn leaves, flowers and fruits $-7.125 \mathrm{ml}$; extract of motherwort herbs $1.0 \mathrm{ml}$; melissa leaves extract $-1.0 \mathrm{ml}$; valerian root extract $-0.5 \mathrm{ml}$ ). The drug is indicated for the treatment of various psyche-related disorders: NCD, cardio neurosis, arterial hypertension (1-2 stage), angina (1-2 stage), stressed arrhythmias, and also as a pharmacoprophylaxis for relieving excitement, stress, and emotional lability in chronic stress.

Hawthorn. This plant contains large number of vitamins and other biologically active substances. In berries there are a number of vitamins $\mathrm{A}$ and $\mathrm{K}$, as well as $\mathrm{C}$ and $\mathrm{E}, \mathrm{B}$ group vitamins, saponins and flavonoids, starch and fructose, organic acids, essential oils and pectin, choline and sorbitol. Some substances in the hawthorn are extremely rarely found in other edible fruits and plants. This makes it unique in its kind. For example, ursolic acid, has an antimicrobial effect and promotes vasodilatation [33, 34].

Hawthorn preparations has a light diuretic effect, has antitumor activity and positively affects cardiac stimulation. Acids in the fruit have a positive effect on the skin, have a rejuvenating effect. Due to the use of berries, active regeneration of cells is restored. The beneficial properties of the hawthorn fruit are manifested in the cardiovascular system. Substances from the fruit expand coronary vessels, soften the work of the arteries of the brain, which increases the saturation of the body's blood oxygen. As a result, the number of dizziness and headaches decreases, the sleep is stabilized and the degree of fatigue of the body decreases during the day. It is proved such effects as hypotensive, coronarolytic, antiarrhythmic, cardioprotective. Its uniqueness is precisely in the presence of regulatory, stabilizing action in a variety of cardio neurotic manifestations (tachycardia, cardiac severity, cardialgia, lability of arterial pressure). However, the hawthorn is an effective cardiomaterial. It is characterized by pronounced antihypoxic and antioxidant effects [33-35].

Substances from hawthorn berries strengthen the blood vessels, reduces the level of harmful cholesterol, improves blood coagulation. As a result, the risk of developing atherosclerotic plaques decreases. At the recommended dosage, the contraindications are minimal. First of all, this is an individual intolerance. Caution should be taken during pregnancy and breastfeeding. Gladiolus can cause an increase in the tone of the uterus. Restrictions also apply to patients in the post-stroke period and people with severe kidney disease. Consultation with a doctor, in these cases, is necessary $[36,37]$. 
Available data from 687 individual patients treated with quantified hawthorn extract or placebo in ten studies were pooled [38]. The study analyzed the effect of treatment on the physiological parameters of patients and the symptoms of the disease, as well as the relationship with the severity of the symptoms and sex. Reduced severity of typical symptoms (reduced tolerance to physical activity, exertional dyspnea, weakness, fatigue and palpitation) were associated with more active treatment and in patients with more severe symptoms. At the same time, there was a weak correlation between improvements in MWL, PRHP and symptoms. Accordingly, the effect of treatment of hawthorn extract on physiological results and typical symptoms was modulated according to severity. Taking into account the basic differences, the benefits were comparable in male and female patients with physical inferiority during early chronic heart failure.

A total of 14 clinical trials was screened in the Cochrane database. All studies were randomized, double-blind, and placebo-controlled using hawthorn leaves and flowers. In ten clinical trials, 855 patients with chronic heart failure (Classes I-III according to the Classification of the New York Heart Association). The results were recorded as a weighted mean difference (WMD) with a 95\% confidence interval (CI). For the physiological outcome, the maximum burden of using the hawthorn extract was more significant than placebo (WMD (watts) $5.35,95 \%$ CI 0,71 to 10.00 , $P<0.02, n=380$. Exercise tolerance was significantly higher in patients receiving hawthorn extract (WMD (W/min) 122.76 , 95\% CI 32.74 to 212.78 , $n=98)$. The pressure-heart rate indicator, as an index of oxygen consumption in the heart, also showed a positive decrease in the treatment of hawthorn extract (WMD (mm Hg)/min) -19.22 , $95 \%$ CI -30.46 to $-7.98, n=264)$. Symptoms such as dyspnea and fatigue were significantly improved in the treatment of the gullet compared to placebo (WMD $-5.47,95 \%$ CI -8.68 to -2.26 , $n=239$ ). No mortality and cardiac disease data were reported except for one study in which death was reported (three of them active, one in control) without providing additional information. Side effects reported were rare, mild and transient; They included nausea, dizziness, heart and gastrointestinal complaints [39].

In clinical trials conducted in EU countries, which involved 1780 patients, acute toxicity was not observed. In the European market between 1992 and 2011, about 810 million doses of dry extract of hawthorn leaves and flowers were sold [40].
Motherwort. The plant contains such useful substances as alkaloids, glycosides, polysaccharides, saponins, tannins, essential oils, vitamins. The mechanism of action of the vestibula is determined by its activating effect on the gamma-aminobutyric acid (GABA) receptors, as well as the normalization of the neurotransmitter balance - an increase in the activity of the inhibitory GABA-ergic and the weakening of the activating catecholaminergic systems of the brain due to its modulating effect on the release, reuptake and receptor binding in said systems [41].

In addition to the central sedative, mild antianxiety and hypnotic action, motherwort preparations have valuable in the conditions of vegetativevascular dystonia, antispasmodic, antihypertensive and anti-anginal effects, increases cardiac output and slows down the heart rate [42].

Thus, in official medicine, motherwort is prescribed in cases of neurosis (its various forms), hysteria, myocarditis, cardiosclerosis, cardiovascular insufficiency I-II degree. In traditional medicine it is used at various nervous upsets, frightened, hypertension; it also helps to improve sleep and general well-being. There are no particularly serious contraindications, but it is not recommended to use it for hypotension. With prolonged use, it can cause an allergic reaction up to complete intolerance, but it is very rare [43, 44].

Motherwort is well known and widely used in Chinese medicine. Reviews [45, 46] give an overview of the chemical composition with an emphasis on biological activity and ethnopharmology. The authors describe the mechanisms that can be the basis of the protective effects in the cardiopulmonary bypass, for example by inhibiting intracellular active forms of oxygen (ROS) and various cellular mechanisms in preventing apoptosis. In addition, the authors say that the peculiarities of modulation of intracellular homeostasis $\mathrm{Ca}^{2+}$ from the side of the thistle can explain its cardiovascular protective effects.

Motherwort, an herbal substance, has been used in the EU for more than 30 years, it has been present in official pharmacopeias for more than 50 years, and continuous use in the form of herbal tea has been recorded for almost 400 years. For example, in 2008, in Lithuania, 98 thousand packets were packed with $25 \mathrm{ml}$ tincture. Over 350,000 packages were sold from 2003 to March 2009 [47].

Valerian. This plant contains in its composition more than 120 chemical components, among which the most important in the clinical plan are essential oils, valipotriates, amino acids, salts of 
organic acids, phenolic compounds, alkaloids, etc. [48]. The main effect of valerian is the sedation of the central nervous system. It also helps to restore emotional balance, cope with headaches, reduce feelings of anxiety and improve working capacity. Positive effect is valerian and cardiovascular system. It is prescribed for an increased heartbeat, with angina pectoris and pain in the heart. Substances contained in the root of the plant, have vasodilator effect.

In Germany, in the 1980-1990's, about 300 clinical trials of combined herbal preparations were conducted, including 10 valerian-based preparations. All valerian-containing preparations according to the criteria of evidence-based medicine were clinically effective in various forms of therapeutic and neurological pathology, especially psychosomatic diseases of the cardiological and gastroenterological profile [49].

Valerian is harmless; however, at high doses and in excess of the course of treatment, unpleasant side effects may occur in the form of reduced performance, drowsiness, lethargy, and also disorders of the function of the gastrointestinal tract. If the remedies made from this plant take longer than two months or substantially exceed recommended doses, gastrointestinal malfunction, depression, drowsiness, nausea and headache may occur. Valerian is contraindicated for people with intolerance to plant components and those suffering from enterocolitis $[50,51]$.

An open, prospective cohort study was conducted in 89 centers in Germany. Valerian was compared with homeopathic preparation Neurexan in 409 people (aged 18 to 75 years), suffering from insomnia. Duration of sleep and insomnia were evaluated based on daily records of patients for 14 days. Sleep quality was estimated at $28 \pm 1$ day. An analysis of the efficacy of therapy after 14 days of treatment showed improved sleep durations compared to baseline in both therapies. Side effects reported: headache, dizziness, paradoxical stimulation, anxiety and cardiac abnormalities [52].

A prospective, unaddressed, non-interventional, observational study was conducted in 49 nationwide centers in Germany on April 3, 2006 (included in the first patient) until December 27, 2006 (the last patient completed the study), which included 807 patients with the following symptoms: anxiety/nervousness, hyperactivity; sleep disturbance; significant phases of insomnia; night anxiety; difficulty concentrating/forgetting; fatigue; absurdity; gloom; gastrointestinal disorders; or headache/pressure using Neurexan versus various vale- rian extracts. There was an improvement in symptoms in both treatment groups. Compliance with the treatment was high: doctors reported "excellent" or "good" compliance for 492 (86.2\%) patients taking the drug and $178(79.5 \%)$ patients in the valerian group. In the group where patients used valerian extracts no side effects were reported [53].

The purpose of another study was to determine whether valerian-lemon balm could contribute to sleep improvement in 100 women during menopause. The study used clinical random testing compared with the control group to study the effect of an herbal supplement containing valerianlemon balm on sleep in menopausal women aged 50-60 years. The sample method consisted of two steps: 1) a non-randomized sample of centers; 2) randomized treatment appointment in each center. The study showed that valerian-lemon balms can improve the duration and quality of sleep in women with sleep disturbances during menopause. In addition, no adverse effects were reported in the treatment process [54].

There is a high degree of use of valerian root drugs in the EU member states: according to IMS Health, the sales of valerian root in the EU in 2002 exceeded 50 million units. Almost 50\% were sold in Germany. The following side effects were noted which may be related to the consumption of the valerian root: symptoms on the side of the gastrointestinal tract, such as nausea, colic in the abdomen (frequency unknown). In the EU, the traditional use of herbal substance valerian and its preparations is considered to be a positive risk group due to minimal side effects [55].

Melissa. The plant contains a large number of organic acids, saponins, flavonoids, resins, tannins, tannins, essential oils. It is possible to continue the list with such trace elements as copper, manganese, iron, potassium, selenium, zinc, magnesium, calcium, and also vitamins of groups $\mathrm{B}$ and $\mathrm{C}$.

Amber acid, which is a part of Melissa, is one of the strongest natural antioxidants, effectively protecting cells of the brain and peripheral organs from the effects of free radicals, which are inevitable companions of chronic stress. Melissa also has the properties of a psychoemotional stabilizer and a cognitive activator (improving mood and cognitive functions, possibly through a modulating effect on the cholinergic and monoaminergic systems of the brain), and spasmolytic action [56].

Prolonged use of medication with Melissa stimulates the medication reduces arterial pressure, relieves nervous tension, which manifests itself by night shake. Melissa is a diuretic that helps to 
normalize heart rhythm dysfunction, as it can quickly and effectively reduce heart rate, which increases the life span of an organism. In addition to enhancing the cardiac function, Melissa is able to control the metabolic processes of the body, enhance the functions of the liver, brain, eliminate heat, and remove bile from the body [57].

There are no strict contraindications for taking medication with Melissa. But there are some points in which its use is not recommended by doctors. These include hypotension, a work in which an increased concentration of attention is required, motor activity, rapid psychological reaction (for example, the work of the motor vehicle driver) $[57,58]$.

Melissa is a traditional herbal remedy for use in the indicated indications, solely on the basis of long-term use. Traditional use of Melissa is following: traditional herbal preparation for the relief of mild symptoms of mental stress and insomnia; traditional medicinal herbal preparation for the symptomatic treatment of minor complaints of gastrointestinal manifestations, including abdominal distension and flatulence $[57,58]$.

Complex action of phytopreparation characteristics and risk assessment. Optimization of the pharmacotherapy of vegetative-vascular dystonia and, in particular, neuro-circulatory dystonia can be achieved through the use of combined preparations containing all the above-mentioned components (hawthorn, motherwort, melissa, valerian). This seems to be all the more justified that these medical herbs are characterized by a high degree of safety. Their application in therapeutic doses, both in mono-form and in various combinations, demonstrated a minimal risk of side effects coming nearer to placebo. In essence, all the side effects of these agents are associated either with individual intolerance, or with a substantial excess of therapeutic doses and are characterized by increased sedation, drowsiness and weakness (for valerian, motherwort, and melissa) or minor dyspeptic disorders, hypotension, bradycardia (for hawthorn). Based on the dose dependence of all the main effects of these plants, the elimination of these side effects is easily achieved by reducing the dose of the preparation.

Phytopreparation can be prescribed to young people as an independent therapy for functional disorders (autonomic dysfunction syndrome), chronic fatigue syndrome, elderly patients with age-related cardiovascular changes, and decreased exercise tolerance when active therapy (antihypertensive, symptomatic treatment of CHD) is not yet shown. Phytopreparation increases the efficiency of complex therapy of arterial hypertension, coronary artery disease, heart failure as a symptomatic remedy due to the content of hawthorn. Along with regular use, it is possible to receive the preparation "on demand" in people who are prone to excessive vegetative reactions to social stimuli, with significant physical activity, accompanied by palpitations and shortness of breath, as well as with meteosensitivity [59].

Comprehensive, combined multimodal neurotropic, cardiopulmonary and vasotropic effect of the preparation - sedative, antihypertensive, antiarrhythmic, coronarolytic, cardioprotective, vegetative stabilizing. It is such an effect that is necessary for the successful treatment of various manifestations of vegetative dystonia both from the central nervous system and from the cardiovascular system, it is this combination of ingredients that allows you to carry out not just symptomatic, but pathogenetically substantiated therapy with maximum correction of disorders of the mechanisms of central regulation of autonomic functions and psycho-emotional balance. At the same time phytopreparation, in contrast to phenobarbital-containing drugs, does not cause addiction and rejection syndrome, does not show excessive sedation and sedation, can support in the process of treatment, a full level of social activity.

Despite the fact that the preparation consists of individual herbal medicines, it should be evaluated as the only active drug (the Table).

Table: Basic safety issues

\begin{tabular}{|l|l|}
\hline $\begin{array}{l}\text { Nature of the risk } \\
\text { factors }\end{array}$ & \multicolumn{1}{c|}{ Unfavorable (side) effects } \\
\hline $\begin{array}{l}\text { Important identi- } \\
\text { fied risks }\end{array}$ & $\begin{array}{l}\text { Reactions of hypersensitivity. } \\
\text { Depression and other disorders } \\
\text { accompanied by inhibition of the } \\
\text { central nervous system. } \\
\text { Pronounced arterial hypotension. } \\
\text { Bradycardia }\end{array}$ \\
\hline $\begin{array}{l}\text { Important poten- } \\
\text { tial risks }\end{array}$ & Severe liver dysfunction \\
\hline $\begin{array}{l}\text { Lack of informa- } \\
\text { tion }\end{array}$ & $\begin{array}{l}\text { The use of preparation during } \\
\text { pregnancy and breastfeeding. } \\
\text { Application of the drug to child- } \\
\text { ren }\end{array}$ \\
\hline
\end{tabular}

Medicinal herbs that are part of the phytopreparation have long-standing traditions of use as sedative or auxiliary substances for sleep. Publications over the last 20 years, several hundred scientific studies with a participation of 5200 participants, have confirmed the positive effects that de- 
teriorate the benefits of using valerian in sleep disorders [60]. Reports of the European Medicines Agency for Leonurus cardiaca L., herba, Crataegus folii, fructus spp., and Melissa officinalis L. recognize the traditional use of herbal medicinal products for nerve stress, nerve heart complaints and sleep disturbances [40, 47, 55, 58].

Diseases that arise in connection with the deterioration of the psycho-emotional background (the effect on the body of various stress factors, causing mood disorders and depression), dramatically reduce efficiency and cause suffering, both the patient and his relatives. Numerous studies show that they are like cardiovascular diseases becoming one of the most common pathologies. Thus, about 19 million people in the United States suffer from depression, which is approximately $10 \%$ of the total population. According to $\mathrm{WHO}$, depressive disorders in 2000 accounted for $40 \%$ of all mental illnesses registered in the world. In practically all developed countries, health authorities are concerned about the current situation and are working to develop different ways to implement it. The effectiveness of modern antidepressants does not exceed $70 \%$, and about one third of people suffering from depression, are resistant to the used drugs, which prompts intensive search for new antidepressants. Admission of psychotropic drugs not only improves the quality of life, but also prevents the development of somatic pathologies. In connection with this, a very promising direction is the use of medicinal plants as sources of combined medications. Side effects in phytotherapy occur much less often and the effect of drugs is much softer, which contributes to their use in the initial stages of the disease, and especially for prevention. Among medicines for the correction of the psycho-emotional state a special place is taken by sedative drugs that are given without a prescription, often they are used without consulting a physician [61, 62].

\section{Conclusions}

The prevalence, seriousness and severity of the course of all manifestations of neurocirculatory dystonia, stress, nervous excitement, heart neurosis, especially with disproportionate approaches to the treatment of these diseases, is a serious medical and social problem.

Given the proven efficacy of the use of Carvelis preparation components, and also that the risks are predictable, and their occurrence can be countered (if not prescribed to a group of patients who have contraindications), and if they occur it can be effectively suppress with other drugs, the benefit of using the phytopreparation prevails above the risks.

\section{References}

[1] Marchenko A. Pharmacovigilance in Ukraine. Key aspects of drug safety. Apteka. 2017;4.

[2] Bagheri H, Laroche M, Montastruc J. Pharmacovigilance: the new challenges. Thérapie. 2016;71(2):121-2. DOI: 10.1016/j.therap.2016.02.019

[3] Beninger P. Opportunities for collaboration at the interface of pharmacovigilance and manufacturing. Clin Ther. 2017;39(4):702-12. DOI: 10.1016/j.clinthera.2017.03.010

[4] Wise L, Parkinson J, Raine J, Breckenridge A. New approaches to drug safety: a pharmacovigilance tool kit. Nat Rev Drug Discov. 2009;8(10):779-82. DOI: 10.1038/nrd3002

[5] Shaw D, Graeme L, Pierre D, Elizabeth W, Kelvin C. Pharmacovigilance of herbal medicine. J Ethnopharmacol. 2012;140(3):513-8. DOI: 10.1016/j.jep.2012.01.051

[6] Kovalenko VM. Stress and cardiovascular disease: the current state of the problem. Ukr Cardiol J. 2015;1:4-10.

[7] Shcherbatykh YuV. Psychology of stress. Moscow: Eksmo; 2008. 304 p.

[8] Hannah TJ, Stellman SD, Morabia A, Miller-Archie SA, Alper H, Laskaris Z, et al. Cardiovascular disease hospitalizations in relation to exposure to the September 11, 2001 World Trade Center disaster and posttraumatic stress disorder. J Am Heart Assoc. 2013;2(5):e000431. DOI: 10.1161/JAHA.113.000431

[9] Iso H, Date C, Yamamoto A, Toyoshima H, Tanabe N, Kikuchi S, et al. Perceived mental stress and mortality from cardiovascular disease among Japanese men and women: the Japan collaborative cohort study for evaluation of cancer risk sponsored by Monbusho (JACC Study). Circulation. 2002;106(10):1229-36. DOI: 10.1161/01.CIR.0000028145.58654.41

[10] Nabi H, Kivimäki M, Batty G, Shipley M, Britton A, Brunner E, et al. Increased risk of coronary heart disease among individuals reporting adverse impact of stress on their health: the Whitehall II prospective cohort study. Europ Heart J. 2013;34(34):2697-2705. DOI: 10.1093/eurheartj/eht216

[11] Alhurani AS, Dekker R, Ahmad M, Miller J, Yousef KM, Abdulqader B, et al. Stress, cognitive appraisal, coping, and event free survival in patients with heart failure. Heart Lung. 2018;47(3):205-10. DOI: 10.1016/j.hrtlng.2018.03.008 
[12] Blumenthal JA, Feger BJ, Smith PJ, Watkins LL, Jiang W, Davidson J, et al. Treatment of anxiety in patients with coronary heart disease: rationale and design of the UNWIND randomized clinical trial. Am Heart J. 2016;176:53-62. DOI: 10.1016/j.ahj.2016.03.003

[13] Scott S, Thompson J. Drugs acting on the heart: heart failure and coronary insufficiency. Anaesthesia Intens Care Med. 2012;13(8):378-83. DOI: 10.1016/j.mpaic.2012.05.008

[14] Loganovsky K. Vegetative-vascular dystonia and osteoalgetic syndrome or chronic fatigue syndrome as a characteristic aftereffect of radioecological disaster. J Chronic Fatigue Syndrome. 2000;7(3):3-16. DOI: 10.1300/J092v07n03_02

[15] Sidorenko GI. Neurocirculatory dystonia (does this disease exist?) Kardiologiia. 2003;43(10):93-8.

[16] Smetanina KI, Ryazanova RM. Phytotherapeutic approach to treatment of cardiac neuroses. Phytotherapy (Ukraine). 2004;3:7-15.

[17] Frolova NL, Chutko LS, Surushkina SIu. Neurocirculatory asthenia: psychoautonomic features and treatment possibilities. Zh Nevrol Psikhiatr Im SS Korsakova. 2012;112(12):51-4.

[18] Amos T, Stein DJ, Ipser JC. Pharmacological interventions for preventing post-traumatic stress disorder (PTSD). Cochrane Database Syst Rev. 2014 Jul 8;7:CD006239. DOI: 10.1002/14651858.CD006239.pub2

[19] Hernandorena I, Duron E, Vidal J, Hanon O. Treatment options and considerations for hypertensive patients to prevent dementia. Expert Opinion on Pharmacotherapy. 2017;18(10):989-1000. DOI: 10.1080/14656566.2017.1333599

[20] Lackland D, Weber M. Global burden of cardiovascular disease and stroke: hypertension at the core. Canad J Cardiol. 2015;31(5):569-71. DOI: 10.1016/j.cjca.2015.01.009

[21] Parati G, Antonicelli R, Guazzarotti F, Paciaroni E, Mancia G. Cardiovascular effects of an earthquake: direct evidence by ambulatory blood pressure monitoring. Hypertension. 2001;38(5):1093-5. DOI: 10.1161/hy1101.095334

[22] Tobin KJ. Stable Angina Pectoris: What does the current clinical evidence tell us? J Am Osteopat Assoc. 2010;110(7):364-70.

[23] Hombach V, Hoher M, Kochs M, Eggeling T, Schmidt A, Hopp H, et al. Pathophysiology of unstable angina pectoris correlations with coronary angioscopic imaging. Europ Heart J. 1988;9(suppl N):40-5. DOI: 10.1093/eurheartj/9.suppl_N.40

[24] Sedighi M, Bahmani M, Asgary S, Beyranvand F, Rafieian-Kopaei M. A review of plant-based compounds and medicinal plants effective on atherosclerosis. J Res Med Sci. 2017;22:30. DOI: 10.4103/1735-1995.202151

[25] Orekhov A, Ivanova E. Cellular models of atherosclerosis and their implication for testing natural substances with antiatherosclerotic potential. Phytomedicine. 2016;23(11):1190-7. DOI: 10.1016/j.phymed.2016.01.003

[26] Dimsdale JE. Psychological stress and cardiovascular disease. J Am College Cardiol. 2008;51(13):1237-46. DOI: 10.1016/j.jacc.2007.12.024

[27] Dolzhenko MN. Three names for one disease, or how to treat a vegetative crisis? Arterial Hypertension (Ukraine). 2008;1:55-62.

[28] Burchinsky SG. Small neuroleptics in the pharmacotherapy of psychosomatic disorders. Health of Ukraine. 2012;3(22):24-5.

[29] Burchinsky SG. The possibilities of complex pharmacotherapy of autonomic dysfunction and psychoemotional imbalance. Family Medicine (Ukraine). 2014;5(55):25-30.

[30] Ghicavii V, Podgurschi L, Pogonea I, Rakovski T. Peculiarities of using drugs in the elderly. Moldov Med J. 2017;60(4):20-4. DOI: 10.5281/zenodo.1106597

[31] Rosic S, Kendic S, Rosic M. Phytoestrogens impact on menopausal symptomatology. Materia Socio-Medica. 2013;25(2):98100. DOI: $10.5455 / \mathrm{msm} .2013 .25 .98-100$

[32] Wojtczak D, Kasznicki J, Drzewoski J. Pros and cons of polypharmacy in elderly patients with diabetes. Clin Diabetol. 2017;6(1):34-8. DOI: 10.5603/DK.2017.0006

[33] Phipps J, O'Kennon R, Lance R. Hawthorns and medlars. Portland: Timber Press; 2003.

[34] Furey A, Tassell M, Kingston R, Gilroy D, Lehane M. Hawthorn (Crataegus spp.) in the treatment of cardiovascular disease. Pharmacognosy Rev. 2010;4(7):32. DOI: 10.4103/0973-7847.65324

[35] Bernatoniene J, Trumbeckaite S, Majiene D, Baniene R, Baliutyte G, Savickas A, et al. The effect of crataegus fruit extract and some of its flavonoids on mitochondrial oxidative phosphorylation in the heart. Phytotherapy Res. 2009;23(12):1701-7. DOI: $10.1002 /$ ptr.2815

[36] Fong H, Bauman J. Hawthorn. J Cardiovasc Nursing. 2002;16(4):1-8. DOI: 10.1097/00005082-200207000-00002

[37] Rigelsky JM, Sweet BV. Hawthorn: Pharmacology and therapeutic uses. Am J Health-System Pharmacy. 2002;59:417-22.

[38] Eggeling T, Regitz-Zagrosek V, Zimmermann A, Burkart M. Baseline severity but not gender modulates quantified Crataegus extract effects in early heart failure - a pooled analysis of clinical trials. Phytomedicine. 2011;18(14):1214-9. DOI: 10.1016/j.phymed.2011.06.022

[39] Pittler MH, Guo R, Ernst E. Hawthorn extract for treating chronic heart failure. Cochrane Database Syst Rev. 2008;(1):CD005312. DOI: 10.1002/14651858.CD005312.pub2 
[40] Assessment report on Crataegus spp., folium cum flore. Based on Article 16d(1), Article 16f and Article 16h of Directive 2001/83/EC as amended (traditional use). 13 October 2014. EMA/HMPC/159076/2014. Committee on Herbal Medicinal Products (HMPC).

[41] Schenwick JP. Phytoantioxidants in clinical practice. Drugs Clin Ther. 2008;14:46-59.

[42] Babushkina AV. Combination preparation Kratal in the treatment of cardiovascular diseases. Ukr Med J. 2010;4(7-8):1-15.

[43] Zhang RH, Liu ZK, Yang DS, Zhang XJ, Sun HD, Xiao WL. Phytochemistry and pharmacology of the genus Leonurus: the herb to benefit the mothers and more. Phytochemistry. 2018;147:167-83. DOI: 10.1016/j.phytochem.2017.12.016

[44] Wojtyniak K, Szymański M, Matławska I. Leonurus cardiaca L. (motherwort): a review of its phytochemistry and pharmacology. Phytother Res. 2013;27(8):1115-20. DOI: 10.1002/ptr.4850

[45] Shang X, Pan H, Wang X, He H, Li M. Leonurus japonicus Houtt.: ethnopharmacology, phytochemistry and pharmacology of an important traditional Chinese medicine. J Ethnopharmacol. 2014;152(1):14-32. DOI: 10.1016/j.jep.2013.12.052

[46] Liu XH, Pan LL, Zhu YZ. Active chemical compounds of traditional Chinese medicine Herba Leonuri: Implications for cardiovascular diseases. Clin Exp Pharmacol Physiol. 2012;39(3):274-82. DOI: 10.1111/j.1440-1681.2011.05630.x

[47] Assessment report on Leonurus cardiaca L., herba. 6 May 2010 EMA/HMPC/127430/2010 Committee on Herbal Medicinal Products (HMPC).

[48] Kornievskaya VG, Sur SV, Lesik IP. Valerian medicinal essential oil. Pharmaceut J (Ukraine). 2000;3:95-9.

[49] Wagner H. Phytomedicine research in Germany. Environ Health Perspect. 1999;107:779-819. DOI: 10.1289/ehp.99107779

[50] Leach MJ, Page AT. Herbal medicine for insomnia: a systematic review and meta-analysis. Sleep Med Rev. 2015;24:1-12. DOI: $10.1016 /$ j.smrv.2014.12.003

[51] Bega D, Malkani R. Alternative treatment of restless legs syndrome: an overview of the evidence for mind-body interventions, lifestyle interventions, and neutraceuticals. Sleep Med Rev. 2016;17:99-105. DOI: 10.1016/j.sleep.2015.09.009

[52] Waldschütz R, Klein P. The homeopathic preparation Neurexan vs. valerian for the treatment of insomnia: an observational study. Sci World J. 2008;8:411-20. DOI: 10.1100/tsw.2008.61

[53] Hubner R, van Haselen R, Klein P. Effectiveness of the homeopathic preparation Neurexan compared with that of commonly used valerian-based preparations for the treatment of nervousness/restlessness - an observational study. Sci World J. 2009;9:733-45. DOI: 10.1100/tsw.2009.95

[54] Taavoni S, Nazem Ekbatani N, Haghani H. Valerian/lemon balm use for sleep disorders during menopause. Complement Ther Clin Pract. 2013;19(4):193-6. DOI: 10.1016/j.ctcp.2013.07.002

[55] Assessment report on Valeriana officinalis L., radix and Valeriana officinalis L., aetheroleum. 7 July 2015 EMA/HMPC/150846/2015 Committee on Herbal Medicinal Products (HMPC).

[56] Kennedy DO, Scholey AB, Tildesley NT, Perry EK, Wesnes KA. Modulation of mood and cognitive performance following acute administration of Melissa officinalis (lemon balm). Pharmacol. Biochem. Behav. 2002;72:953-964.

[57] Shakeri A, Sahebkar A, Javadi B. Melissa officinalis L. - a review of its traditional uses, phytochemistry and pharmacology. J Ethnopharmacol. 2016;188:204-28. DOI: 10.1016/j.jep.2016.05.010

[58] Committee on herbal medicinal products (hmpc), community herbal Monograph on melissa officinalis 1., folium, London, 8 may 2007 doc. ref. emea/hmpc/5341/2007.

[59] Prihodko VY. Clinical experience of using the drug Karvelis in patients of different age groups with autonomic dysfunction. Health of Ukraine. 2014;19:38-9.

[60] Ross SM. Psychophytomedicine: an overview of clinical efficacy and phytopharmacology for treatment of depression, anxiety and insomnia. Holist Nurs Pract. 2014;28:275-80. DOI: 10.1097/HNP.0000000000000040

[61] Luo S, Mai L, Zhu Z. Separation and determination of alkaloids of Leonurus cardiaca. Zhongyao Tongbao. 1985;10(1):32-5.

[62] Kosyakova LE. Healing plants: A handbook of folk and practical phytotherapy. Yaroslavl: Verkhne-Volzhskoye Publishing House; 1993. 272 p.

Н.О. Горчакова, Е. Хеймуллер, О.Ю. Галкін

\section{СУЧАСНІ ДАНІ ПРО БЕЗПЕЧНІСТЬ КОМПЛЕКСНОГО РОСЛИННОГО ПРЕПАРАТУ ІЗ СЕДАТИВНИМИ I КАРДІОПРОТЕКТОРНИМИ ВЛАСТИВОСТЯМИ}

Проблематика. План управління ризиками $є$ одним із основних документів системи фармакологічного нагляду - документ присвячений плануванню діяльності з фармаконагляду та мінімізації ризиків. Збільшення використання рослинних лікарських засобів приводить до розширення знань щодо токсичного впливу лікарських рослин та побічних ефектів. У цьому випадку фрармаконагляд має надзвичайно важливе значення для виявлення й аналізу небажаних реакцій. Одним із рослинних препаратів, що широко застосовуються для підтримки серцево-судинної системи під впливом стресу, при нейроциркуляторній дистонії, неврозі серця, у комплексному лікуванні артеріальної гіпертензії, стенокардії, аритмії, є комплексний лікарський засіб Карвеліс, краплі 
оральні, розчин. Активними фармацевтичними інгредієнтами препарату є екстракти із суміші листя, квітів і плодів глоду, трави собачої кропиви, листя меліси, кореня валеріани.

Мета. Критичний аналіз сучасних наукових даних про співвідношення користі та ризику комплексного фрітопрепарату із седативними та кардіопротекторними властивостями.

Результати. Проаналізовано патофізіологічну та епідеміологічну характеристику таких нозологічних фрорм: стрес, нейроциркуляторна дистонія, невроз серця, артеріальна гіпертензія, стенокардія, аритмія. Узагальнено поточні дані щодо безпеки фітопрепарату та співвідношення користі та ризику. Доступні клінічні дані було проаналізовано для окремих фітокомпонентів або їх комбінацій.

Висновки. Поширеність, серйозність і тяжкість перебігу всіх проявів нейроциркуляторної дистонії, стресу, нервового збудження, серцевого неврозу, особливо з непропорційними підходами до лікування цих захворювань, є серйозною медико-соціальною проблемою. 3 огляду на підтверджену ефективність використання компонентів препарату Карвеліс, а також на те, що ризики є передбачуваними, їх виникнення може бути ефективно подолане, перевага використання фітопрепарату переважає над ризиками. Ключові слова: фрармакологічний нагляд; план управління ризиками; глід; собача кропива; валеріана; меліса.

\section{Н.А. Горчакова, Э. Хеймуллер, А.Ю. Галкин}

\section{ТЕКУЩИЕ ДАННЫЕ ПО БЕЗОПАСНОСТИ КОМПЛЕКСНОГО РАСТИТЕЛЬНОГО ПРЕПАРАТА С СЕДАТИВНЫМИ И КАРДИОПРОТЕКТОРНЫМИ СВОЙСТВАМИ}

Проблематика. План управления рисками является одним из основных документов системы фармакологического надзора документ посвящен планированию деятельности по фармаконадзору и минимизации рисков. Увеличение использования растительных лекарственных средств приводит к расширению знаний о токсическом действии лекарственных растений и побочных эффектах. В данном случае фрармаконадзор играет чрезвычайно важное значение для выявления и анализа нежелательных реакций. Одним из растительных препаратов, широко применяющихся для поддержания сердечно-сосудистой системь при стрессе, нейроциркуляторной дистонии, неврозе сердца, в комплексном лечении артериальной гипертензии, стенокардии, аритмии является комплексный препарат Карвелис, капли оральные, раствор. Действующими компонентами препарата являются экстракты из смеси листьев, цветов и плодов боярышника, травы пустырника, листьев мелиссы, корня валерианы.

Цель. Критический анализ современных научных данных о соотношении пользы и риска комплексного фитопрепарата с седативными и кардиопротекторными свойствами.

Результаты. Проанализирована патофизиологическая и эпидемиологическая характеристика следующих нозологических форм: стресс, нейроциркуляторная дистония, невроз сердца, артериальная гипертензия, стенокардия, аритмия. Обобщенны текущие данные о безопасности фитопрепарата и соотношении пользы и риска. Доступные клинические данные были проанализированы для отдельных фитокомпонентов или их комбинаций.

Выводы. Распространенность, серьезность и тяжесть течения всех проявлений нейроциркуляторной дистонии, стресса, нервного возбуждения, сердечного невроза, особенно с непропорциональными подходами к лечению этих заболеваний, являются серьезной медико-социальной проблемой. С учетом подтвержденной эффективности использования компонентов препарата Карвелис, а также того, что риски являются предсказуемыми, их возникновение может быть эффективно преодолено, преимущество использования фитопрепарата преобладает над рисками.

Ключевые слова: фрармакологический надзор; план управления рисками; боярышник; пустырник; валериана; мелисса. 